\title{
Rainbow trout somatostatin receptor subtypes SSTR1A, SSTR1B, and SSTR2 differentially activate the extracellular signal-regulated kinase and phosphatidylinositol 3-kinase signaling pathways in transfected cells
}

\author{
Alison L Hagemeister, Jeffrey D Kittilson, Heather E Bergan and Mark A Sheridan \\ Department of Biological Sciences, North Dakota State University, Department 2715, PO Box 6050, Fargo, North Dakota 58108-6050, USA \\ (Correspondence should be addressed to M A Sheridan; Email: mark.sheridan@ ndsu.edu)
}

\begin{abstract}
Previously, we reported that extracellular signal-regulated kinase (ERK) and protein kinase B (Akt), a downstream target of phosphatidylinositol 3-kinase (PI3K), mediated somatostatin (SS) inhibition of GH receptor, IGF1, and IGF1 receptor expression. In this study, we used Chinese hamster ovary-K1 cells that stably transfected individually with trout SS receptors (SSTR1A, SSTR1B, and SSTR2) to elucidate receptor-effector pathway linkages. SS induced ERK and Akt activation in a time- and concentration-related manner in all SSTR-expressing cells; however, the PI3K/Akt pathway was activated to a greater extent through SSTR1A than through either SSTR1B or SSTR2, whereas the ERK pathway was activated to a greater extent though SSTR2 than through either SSTR1A or SSTR1B. Although the ERK pathway inhibitor U0126 had no effect on Akt activation, the PI3K inhibitor LY294002 reduced ERK activation to near control levels in all SSTR-expressing cell lines, suggesting some cross talk between the pathways, possibly at the level of c-Raf, the phosphorylation of which also was induced by SS via each SSTR. Pertussis toxin (PTX) completely abolished SS-induced activation of ERK and Akt in SSTR1A-, SSTR1B-, and SSTR2-expressing cells, suggesting that these receptors link to the ERK and PI3K/Akt pathways via PTX-sensitive G-proteins. SS-induced activation of Elk1, Stat3, and $\mathrm{C} / \mathrm{EBP} \beta$ also was mediated by each of the trout SSTRs. These findings establish important receptor-effector pathway linkages for fish SSTRs and provide insight into the molecular mechanisms by which SSs may elicit diverse physiological effects in target cells.
\end{abstract}

Journal of Molecular Endocrinology (2010) 45, 317-327

\section{Introduction}

The somatostatin (SS) family of peptide hormones regulates numerous growth, metabolic, developmental, and other processes in vertebrates (Klein \& Sheridan 2008, Van Op den bosch et al. 2009, Gahete et al. 2010, Sheridan \& Hagemeister 2010). Since the discovery of the first SS, SS-14, from the hypothalamus of sheep, related peptides ranging in length from 14 to 37 amino acids and varying in amino acid composition have been isolated from representatives of every extant class of vertebrate (Nelson \& Sheridan 2005). The molecular heterogeneity of the SS family arises from the tissuespecific processing of the SS precursor, preprosomatostatin (PPSS), and, in fish, from the existence of multiple genes that encode distinct PPSS molecules (Sheridan et al. 2000, Tostivint et al. 2008).

SS elicits its actions by binding to SS receptors (SSTRs), which are members of the rhodopsin subfamily of G-protein-coupled receptors. In mammals, five subtypes of SSTRs have been characterized
(SSTR 1-5; Moller et al. 2003, Siehler et al. 2008). Four SSTR subtypes have been characterized in fish (homologous to mammalian SSTR1, 2, 3, and 5); some of which possess multiple isoforms, depending on species (SSTR1A/1B, 3A/3B/3C, and 5A/5B; Lin \& Peter 2001, Nelson \& Sheridan 2005). In fish and mammals, SSTRs are widely distributed (commensurate with the diverse actions of SS); multiple SSTR subtypes are displayed on native target cells such that the heterogeneous complement of SSTRs is differentially expressed in a tissue-specific manner, and individual SSTRs have distinct yet overlapping ligand-binding and agonist-induced regulation features (Sheridan et al. 2000, Gong et al. 2004, Siehler et al. 2005, 2008). Studies in fish revealed that the pattern of SSTR subtype expression is regulated by nutritional state and hormones such as GH, insulin-like growth factor 1 (IGF1), and insulin (Nelson \& Sheridan 2005).

Post-receptor signaling events for SS in mammalian systems are fairly well characterized and involve numerous effectors, including adenylyl cyclase, 
phospholipase C (PLC), various ion channels and exchangers, mitogen-activated protein kinases (MAPKs), and several other kinases and phosphatases (Cervia \& Bagnoli 2007). Specific linkages between SSTR subtypes and particular effector pathways and biological responses also are known. For example, SSTR1 and SSTR2 in human and rat cell lines link to extracellular signal-regulated kinase (ERK) subfamily of MAPKs and to the phosphatidylinositol 3-kinase (PI3K)/protein kinase B (Akt) pathway (Valatas et al. 2004, Liu \& Wong 2005, Ghosh et al. 2006). In addition, mammalian SSTR1 mediates SS inhibition of cell proliferation, whereas SSTR2 appears to mediate SS inhibition of pituitary GH and pancreatic insulin (Florio et al. 2000, Sheridan et al. 2000). Far less has been reported about the mechanism(s) of SS action in fish, and virtually nothing is known about SSTR-effector pathway biological response linkages. Recently, we reported that SS activates the ERK and PI3K/Akt pathways in liver and gill filaments of rainbow trout, and that these signal cascades play a role in SS-inhibited expression of GH, IGF1, and IGF1 receptor (IGFR; Hagemeister \& Sheridan 2008, Hanson et al. 2010).

The objective of this study was to establish receptoreffector pathway linkages for fish SSTRs. To this end, Chinese hamster ovarian (CHO) cells were individually transfected with plasmids that contained cDNAs encoding rainbow trout SSTR subtypes 1A, 1B, and 2. The examination of these trout SSTRs provided an unique opportunity to examine effector pathway linkages to different SSTR subtypes as well as to isoforms of SSTR subtypes.

\section{Materials and methods}

\section{Materials}

All chemicals and reagents were purchased from Sigma unless noted otherwise. Phospho-specific and control rabbit antisera for human ERK 1/2 (phosphorylated at $\mathrm{Thr}^{202} / \mathrm{Tyr}^{204}$ ) and AKT (phosphorylated at $\operatorname{Ser}^{473}$ ), human c-Raf (phosphorylated at $\operatorname{Ser}^{259}$ ), human CCAAT/enhancer binding protein $\beta(\mathrm{C} / \mathrm{EBP} \beta)$ (phosphorylated at $\mathrm{Thr}^{235}$ ), human E-26-like gene 1 (ELK1) (phosphorylated at $\mathrm{Ser}^{383}$ ), and human signal transducers and activators of transcription 3 (STAT3) (phosphorylated at Tyr $^{705}$ ) as well as HRP-linked antirabbit antiserum, PI3K inhibitor LY294002, MEK 1/2 inhibitor U0126, and cell lysis buffer were purchased from Cell Signaling Technology (Beverly, MA, USA); the manufacturer certified that the antisera react with rodent proteins in western analyses. All blue molecular weight markers were from Bio-Rad Laboratories.

\section{Experimental cell cultures}

The CHO cell line (CHO-K1 wild-type) was obtained from the American Type Culture Collection (Rockville, MD, USA). Cells were maintained in $5 \% \mathrm{CO}_{2}$ and $95 \%$ relative humidity at $37^{\circ} \mathrm{C}$ in Ham's $\mathrm{F}-12$ nutrient mixture supplemented with $10 \%$ FCS, $100 \mathrm{U} / \mathrm{ml}$ penicillin, $100 \mu \mathrm{g} / \mathrm{ml}$ streptomycin, and $0.1 \%$ (v/v) fungizone (base medium). For passage, the cells were detached from the culture flasks by washing with PBS followed by brief incubation in trypsin $(0.5 \mathrm{mg} / \mathrm{ml}) /$ EDTA $(0.2 \mathrm{mg} / \mathrm{ml})$. The cells were split every 3 days. For storage, the cells were resuspended in base medium containing dimethyl sulfoxide $(10 \%$ final concentration) and frozen at $-80^{\circ} \mathrm{C}$.

\section{Plasmid construction}

Juvenile rainbow trout (Oncorhynchus mykiss) were obtained, housed, and their tissues were harvested as described previously (Hagemeister \& Sheridan 2008). Total RNA was extracted from rainbow trout liver using TRI Reagent as specified by the manufacturer (Molecular Research Center, Inc., Cincinnati, OH, USA). Each RNA pellet was redissolved in $75 \mu \mathrm{l}$ RNase-free deionized water and quantified by u.v. $\left(\mathrm{A}_{260}\right)$ spectrophotometry, then diluted with RNase-free deionized water to $100 \mathrm{ng} / \mu \mathrm{l}$ and stored at $-80{ }^{\circ} \mathrm{C}$ until use. RNA quality was examined with the Agilent 2100 Bioanalyzer (Santa Clara, CA, USA) prior to use. First-strand cDNA was prepared from total RNA with the Clontech SMART RACE cDNA amplification kit (Clontech Laboratories, Inc.) and was then used as template for PCR using specific primers for each trout SSTR cDNA characterized previously (Slagter \& Sheridan 2004, Kittilson J, Slagter B, Yak T \& Sheridan MA, unpublished; accession numbers are as follows: NM_001124534 (SSTR1A), NM_001124643 (SSTR1B), and HM053471 (SSTR2)). The primer set used to obtain the complete coding region of SSTR1A was 5'-TGAGGTAAACTGGACAAAATGGACAA-3' (forward primer) and $5^{\prime}$-TTCGTTGCTTCCCTATCACTCTCA-3' ${ }^{\prime}$ (reverse primer), the primer set used to obtain SSTR1B was 5'-GGTAAACTGGTCAAATGGAAAACA-3' (forward primer) and 5'-CGTGTGGCATTGTATTTTATCATCT- ${ }^{\prime}$ (reverse primer), and the primer set used to obtain SSTR2 was $5^{\prime}$-TCGGCTGAACGTATTGGAGAG-3 ${ }^{\prime}$ (forward primer) and 5'-GCTTGTGAGGTTGAGGGAGAGT-3' (reverse primer). The PCR was carried out using the Clontech Advantage 2 PCR kit under the following conditions: $94{ }^{\circ} \mathrm{C}$ for $5 \mathrm{~min}$, followed by 35 cycles at $94{ }^{\circ} \mathrm{C}$ for $45 \mathrm{~s}, 60{ }^{\circ} \mathrm{C}$ for $45 \mathrm{~s}$, and $72{ }^{\circ} \mathrm{C}$ for $1 \mathrm{~min}$, and finally ended at $70^{\circ} \mathrm{C}$ for $10 \mathrm{~min}$. The resulting PCR products were visualized by electrophoresis on agarose gels containing $2 \%(\mathrm{w} / \mathrm{v})$ OmniPur Agarose (EM Science, Gibbstown, NJ, USA) 
in $1 \times$ Tris-borate-EDTA buffer followed by ethidium bromide staining and u.v. transillumination. PCR products were cloned directly into the pTarget (Promega) expression vector, which contains the neomycin phosphotransferase gene that confers resistance to the neomycin analog, geneticin (G418). Positive colonies were identified by agarose gel electrophoresis of restriction enzyme digests (EcoRI; Promega) of purified plasmid preparations (Wizard Plus SV Minipreps, Promega Corporation). Plasmid DNA ( $75 \mathrm{fmol}$ ) was sequenced with the CEQ 2000 sequencer using the Dye Terminator Cycle Sequencing Quick Start kit (Beckman Coulter; Fullerton, CA, USA) according to the manufacturer's protocol.

\section{Stable transfection}

Stable transfection of CHO-K1 cells with cDNAs encoding rainbow trout SSTR1A, SSTR1B, and SSTR2 was done as described previously (Gong et al. 2004). Briefly, CHO-K1 cells $\left(\right.$ ca. $4 \times 10^{5}$ ) in $0.4 \mathrm{ml}$ cold PBS were combined with $10 \mu \mathrm{g}$ purified plasmid in a $0.4 \mathrm{~cm}$ gene pulse cuvette. The cuvette was pulsed once for $29 \mathrm{~ms}$ at $960 \mu \mathrm{F}$ and $400 \mathrm{~V}$ in a Gene Pulser Transfection Apparatus (Bio-Rad). The cells were diluted with the base medium, plated, and allowed to grow for $24 \mathrm{~h}$. Selection medium consisting of the base medium with $200 \mu \mathrm{g} / \mathrm{ml}$ (final concentration) G418 was applied to the cultures; after 10-14 days in the selection medium, the G418-resistant clones were subcultured for receptor signaling pathway studies. Four types of subclones were generated: one for each SSTR-encoding cDNA (SSTR1A, SSTR1B, and SSTR2), and one that was transfected with vector only as a control.

To ensure that the established $\mathrm{CHO}$ cell lines were expressing the correct SSTR subtype, CHO cells from each cell line were grown to confluency and trypsinized. Two million cells were collected and washed with PBS, and total RNA was extracted, quantified, and diluted in RNase-free deionized water to $100 \mathrm{ng} / \mu \mathrm{l}$. From $100 \mathrm{ng}$ total RNA, reverse transcription (RT)-PCR was carried out as described above, and the resulting PCR products were separated by agarose gel electrophoresis and visualized by u.v. transillumination following ethidium bromide staining.

\section{Analysis of $\left[{ }^{125} \mathrm{I}\right]$-somatostatin binding}

Analysis of $\left[{ }^{125} \mathrm{I}\right]-\mathrm{SS}-14$ binding was performed on microsomes isolated from clonal lines of CHO-K1 cells transfected with cDNAs encoding rainbow trout SSTR1A, SSTR1B, or SSTR2. Cells were collected by centrifugation $\left(500 \mathrm{~g}\right.$ for $5 \mathrm{~min}$ at $\left.14^{\circ} \mathrm{C}\right)$, then lysed with $100 \mu \mathrm{l} 1 \times$ cell lysis buffer (Cell Signaling Technology) with $1 \mathrm{mM}$ phenylmethylsulfonyl fluoride
(PMSF). Lysates were incubated on ice for $5 \mathrm{~min}$, refluxed 20 times with a micropipette, and then centrifuged at $1000 \mathrm{~g}$ for $30 \mathrm{~min}$ at $4{ }^{\circ} \mathrm{C}$. The supernatant was centrifuged at $15000 \mathrm{~g}$ for $30 \mathrm{~min}$ at $4{ }^{\circ} \mathrm{C}$, and the subsequent supernatant was centrifuged at $110000 \mathrm{~g}$ for $90 \mathrm{~min}$ at $4{ }^{\circ} \mathrm{C}$. The resulting pellet was resuspended in $25 \mathrm{mM}$ Tris- $\mathrm{HCl}$ with $0 \cdot 1 \mathrm{TIU}$ aproti$\mathrm{nin} / \mathrm{ml}$ and $1 \mathrm{mM}$ PMSF, $\mathrm{pH} 7 \cdot 5$. The protein concentration of the microsomal preparation was determined using the Bio-Rad dye binding method for microplates. Binding assays were conducted using the method described by Pesek et al. (1998) with $\left[{ }^{125} \mathrm{I}\right]-\mathrm{Tyr}^{11}$-somatostatin-14 $\quad(74 \mathrm{Tbq} / \mathrm{mmol}$; Amersham Pharmacia Biotech).

\section{Western blotting}

The activation of signaling pathways in transfected cells was determined as described previously (Hagemeister \& Sheridan 2008). In short, the cells were harvested with trypsin, counted, and $2 \times 10^{5}$ cells were seeded into 24-well plates. Cells were allowed to adhere overnight and serum starved for $24 \mathrm{~h}$. The serum-free medium was then removed, and the cells were treated with varying concentrations of SS ranging from 0 to $1000 \mathrm{ng} / \mathrm{ml}(0-610 \mathrm{nM})$ for the period of time specified in the figures. In combination experiments involving MEK and PI3K inhibitors, the specific inhibitor was added $1 \mathrm{~h}$ prior to hormone addition at a concentration recommended to be maximally effective by the manufacturer and which was used previously (Lahlou et al. 2003, Tanel \& Averill-Bates 2007). After treatments, incubations were stopped and the cells were lysed with $100 \mu \mathrm{l} 1 \times$ cell lysis buffer. Lysates were incubated on ice for $10 \mathrm{~min}$ with occasional vortexing and centrifuged at $16000 \mathrm{~g}$ for $10 \mathrm{~min}$ at $4{ }^{\circ} \mathrm{C}$. The supernatant was removed, and the protein concentration was determined using the Bradford protein assay (Bio-Rad Laboratories). Samples containing $20 \mu \mathrm{g}$ total protein were separated on a $7.5 \%$ SDS-PAGE gel and transferred to a $0.45 \mu \mathrm{m}$ nitrocellulose membrane (Bio-Rad Laboratories), which was blocked with 5\% nonfat milk in TBS-Tween 20 (TBST) at room temperature for $1 \mathrm{~h}$. Membranes were washed three times with TBST and incubated with the indicated rabbit antiserum $(1: 1000)$ in 5\% BSA TBST blocking buffer overnight $\left(4^{\circ} \mathrm{C}\right)$. After washing with TBST, the membranes were incubated with goat-anti-rabbit IgG-HRP antiserum (1:2000) in blocking buffer for $1 \mathrm{~h}$, washed, and the blot was detected using ECL detection system (GE Healthcare, Buckinghamshire, UK). The membranes were stripped under reducing conditions (100 mM $\beta$-mercaptoethanol, 2\% SDS, $62.5 \mathrm{mM}$ Tris-HCl $\mathrm{pH} 6.7$ for $30 \mathrm{~min}$ at $50{ }^{\circ} \mathrm{C}$ with occasional agitation), washed twice with TBST, and immunodetection protocol was repeated with respective control antiserum to 
normalize blots. The membranes were scanned, and the bands quantified with a FluorChem FC2 imager (Alpha Innotech Corp., San Leandro, CA, USA).

\section{Statistical analysis}

Quantitative data are expressed as means \pm s.E.M. Statistical differences were estimated by ANOVA followed by Duncan's multiple range test. A probability level of 0.05 was used to indicate significance.

\section{Results}

\section{Independent expression of SSTRs in CHO-K1 cells}

Three distinct full-length cDNAs that encode for rainbow trout SSTR1A, SSTR1B, and SSTR2 were obtained by RT-PCR for transfection into CHO-K1 cells (Fig. 1). The size of the cDNAs (1192 nt for SSTR1A, $1173 \mathrm{nt}$ for SSTR1B, and $1384 \mathrm{nt}$ for SSTR2) matched the values predicted from primer locations. Furthermore, each SSTR-expressing cell line expressed only its target cDNA. For instance, the SSTR1Aexpressing cell line expressed only SSTR1A, and the SSTR1B- and the SSTR2-expressing cell lines expressed only SSTR1B and SSTR2 respectively. Vector onlytransfected cells did not express any of the SSTR mRNAs. Nucleotide sequencing verified that no random mismatching of bp or point mutations occurred during plasmid construction. The SSTR1A and SSTR1B cDNAs both possessed an open reading frame with $1113 \mathrm{nt}$ that encoded for two distinct 371-amino acid proteins, whereas SSTR2 possessed an open reading frame of $1116 \mathrm{nt}$ and encoded for a 372-amino acid protein; these observations were

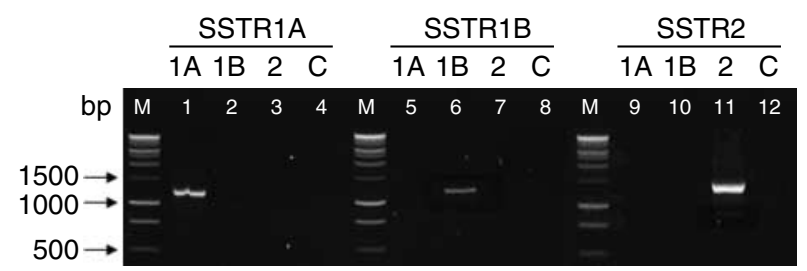

Figure 1 Reverse transcription-PCR amplification of rainbow trout somatostatin receptor subtypes $1 \mathrm{~A}$ (SSTR1A), 1B (SSTR1B), and 2 (SSTR2) in stably transfected $\mathrm{CHO}-\mathrm{K} 1$ cells. Total RNA was extracted from cells transfected with cDNA encoding rainbow trout SSTR1A, SSTR1B, SSTR2, or vector only (control) and subjected to reverse transcription-PCR as described in Materials and methods. Gene-specific primer sets for each SSTR cDNA were used to test each of the cell lines. PCR products were separated by agarose gel electrophoresis and visualized by ethidium bromide staining and u.v. visualization. Lanes 1-4: PCR amplification with SSTR1A primers; lanes 5-8: PCR amplification with SSTR1B primers; lanes 9-12: PCR amplification with SSTR2 primers. M, DNA ladder; 1A, SSTR1A-transfected cells; 1B, SSTR1B-transfected cells; 2, SSTR2-transfected cells; C, vector only-transfected cells.
Table 1 Specific binding of $\left[{ }^{125} \mathrm{l}\right]$-somatostatin to microsomes isolated from Chinese hamster ovary-K1 cells individually transfected with vector only or with vector containing CDNA encoding for rainbow trout SSTR1A, SSTR1B, or SSTR2*

\begin{tabular}{|c|c|c|c|}
\hline Vector only & SSTR1A & SSTR1B & SSTR2 \\
\hline $146 \pm 23^{a}$ & $6745 \pm 327^{b}$ & $7441 \pm 476^{b}$ & $6244 \pm 389^{b}$ \\
\hline
\end{tabular}

*Units of specific binding are counts per minute; data expressed as mean \pm S.E.M. triplicate determinations from three independent experiments; groups with different letters are significantly different from each other $(P<0.05)$.

identical to our previous reports (Slagter \& Sheridan 2004, J Kittilson, B Slagter, T Yak \& MA Sheridan, unpublished).

The functional expression of SSTRs on CHO cells was verified by specific binding of $\left[{ }^{125} \mathrm{I}\right]-\mathrm{SS}$ to microsomes isolated from transfected cells. CHO-K1 cells individually transfected with plasmids containing SSTR1A, SSTR1B, and SSTR2 displayed comparable high levels of $\left[{ }^{125} \mathrm{I}\right]$-SS specific binding, whereas the cells transfected with vector only did not bind $\left[{ }^{125} \mathrm{I}\right]-\mathrm{SS}$ to a significant extent (Table 1). Typically, 40000 c.p.m. of [ $\left.{ }^{125} \mathrm{I}\right]-\mathrm{SS}$ were added to each reaction containing ca. $100 \mu \mathrm{g}$ microsomal protein. Under these conditions, specific binding to SSTR-transfected cells ranged from 12 to $15 \%$ of total radioactivity added and up to $86 \%$ of total $\left[{ }^{125} \mathrm{I}\right]-\mathrm{SS}$ bound; nonspecific binding averaged $\left[{ }^{13} \mathrm{I}\right]$-SS bound; nonspecific binding averaged $13 \cdot 3 \pm 2 \cdot 4 \%$.

\section{SS activates both the ERK and the PI3K signaling pathways}

Phospho-specific and control antibodies were used to study the effects of SSs on activation of the ERK and PI3K pathways. SS treatment of all SSTR-expressing CHO cells induced ERK $1 / 2$ phosphorylation in a timedependent manner (Fig. 2A). For all cell lines, maximal phosphorylation of ERK 1/2 occurred within 10 min; thereafter, activation of the pathway decreased through 180 min. SS also stimulated ERK $1 / 2$ phosphorylation in each of the SSTR-expressing cell lines in a concentration-dependent manner (Fig. 2B). Significant activation of the pathway was observed at SS concentration as low as $1 \mathrm{ng} / \mathrm{ml}$. Notably, the ERK pathway was activated to a greater extent through SSTR2 than through either SSTR1A or SSTR1B.

The proximal activation of the ERK pathway involved the phosphorylation of c-Raf (Fig. 3). SS-stimulated phosphorylation of c-Raf appeared similar through each of the SSTR subtypes. SS induced phosphorylation of c-Raf in a time-dependent manner. In all SSTRexpressing cell lines, the activation of c-Raf increased rapidly to maximum values after $30 \mathrm{~min}$, after which time, the abundance of phospho-c-Raf declined.

SS treatment also activated the PI3K/Akt pathway in a time- and concentration-dependent manner in all of 

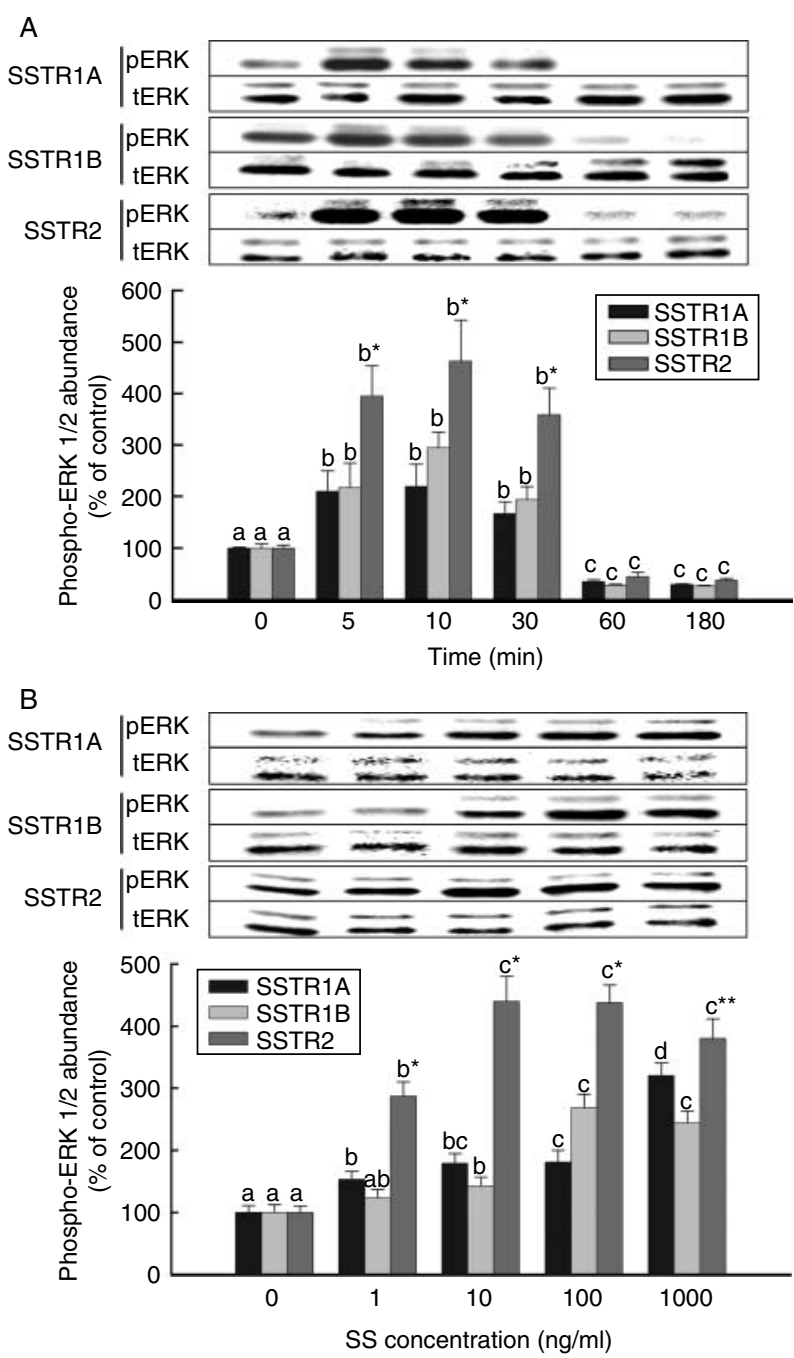

Figure 2 Effects of somatostatin (SS) on the activation of ERK in $\mathrm{CHO}-\mathrm{K} 1$ cells stably transfected with cDNA encoding rainbow trout somatostatin receptor subtype $1 \mathrm{~A}$ (SSTR1A), somatostatin receptor subtype $1 \mathrm{~B}$ (SSTR1B), and somatostatin receptor subtype 2 (SSTR2). (A) Time-dependent phosphorylation of ERK $1 / 2$ in cells incubated with $100 \mathrm{ng} / \mathrm{ml} \mathrm{SS}$. (B) Concentrationdependent phosphorylation of ERK in cells incubated in the absence or presence of varying concentrations of SS for $10 \mathrm{~min}$. Lysates were separated by SDS-PAGE followed by western immunoblotting using phospho-specific (pERK 1/2) and control (total ERK 1/2; tERK 1/2) antibodies. Data are presented as representative immunoblots (insets) and as means \pm S.E.M. $(n=6)$ of blots quantified with an Alphalmager. For a given receptor subtype-expressing cell line (SSTR1A, SSTR1B, SSTR2), groups with different letters are significantly different from each other $(P<0.05) ;{ }^{*}$ indicates significantly different from all other receptor subtype-expressing cell lines at a given time/concentration; ** indicates significantly different from only the SSTR1Bexpressing cell line at a given time/concentration.

the SSTR-expressing cell lines. In contrast to observations with the ERK pathway, maximal activation of Akt did not occur until 30-60 min after SS treatment (Fig. 4A). SS also activated Akt in a concentration-dependent manner; SS significantly increased the abundance of phospho-Akt at concentrations of $1-1000 \mathrm{ng} / \mathrm{ml}$, depending on SSTR subtype (Fig. 4B). The PI3K/Akt pathway was activated to a greater extent through SSTR1A than through either SSTR1B or SSTR2.

The linkage of SSTRs to either the ERK pathway or the PI3K/Akt pathway was confirmed by the use of specific pathway inhibitors (Fig. 5). SS-induced phosphorylation of ERK 1/2 in all SSTR-expressing cell lines was blocked by the MEK inhibitor, U0126. SS-induced phosphorylation of Akt in all SSTR-expressing cell lines was completely blocked by the PI3K inhibitor, LY294002. Interestingly, while the MEK inhibitor had no effect on Akt activation, the PI3K inhibitor reduced ERK activation to near control levels.

\section{Trout SSTRs link to the ERK and PI3K/Akt pathways via pertussis toxin-sensitive G-proteins}

Through treatment of the transfected cell lines with pertussis toxin (PTX), it was demonstrated that the three rainbow trout SSTRs are coupled to PTX-sensitive G-proteins. Cells were pretreated with PTX for $6 \mathrm{~h}$ before treatment with SS, and the effects on ERK 1/2 and Akt phosphorylation were observed. PTX completely abolished SS-induced activation of ERK

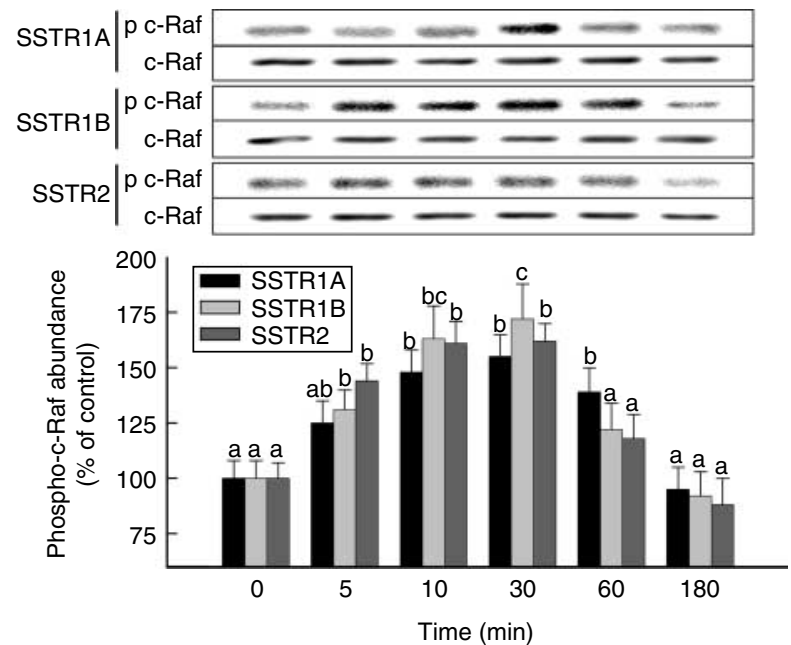

Figure 3 Effects of somatostatin (SS) on the activation of c-Raf in $\mathrm{CHO}-\mathrm{K} 1$ cells stably transfected with CDNA encoding rainbow trout somatostatin receptor subtype 1A (SSTR1A), somatostatin receptor subtype 1B (SSTR1B), and somatostatin receptor subtype 2 (SSTR2). Cells were incubated with $100 \mathrm{ng} / \mathrm{ml} \mathrm{SS}$ for various times, and lysates were separated by SDS-PAGE followed by western immunoblotting using phospho-specific (p c-Raf) and control (total c-Raf) antibodies. Data are presented as representative immunoblots (insets) and as means \pm S.E.M. $(n=6)$ of blots quantified with an Alphalmager. For a given receptor subtype-expressing cell line (SSTR1A, SSTR1B, and SSTR2), groups with different letters are significantly different from each other $(P<0.05)$. 

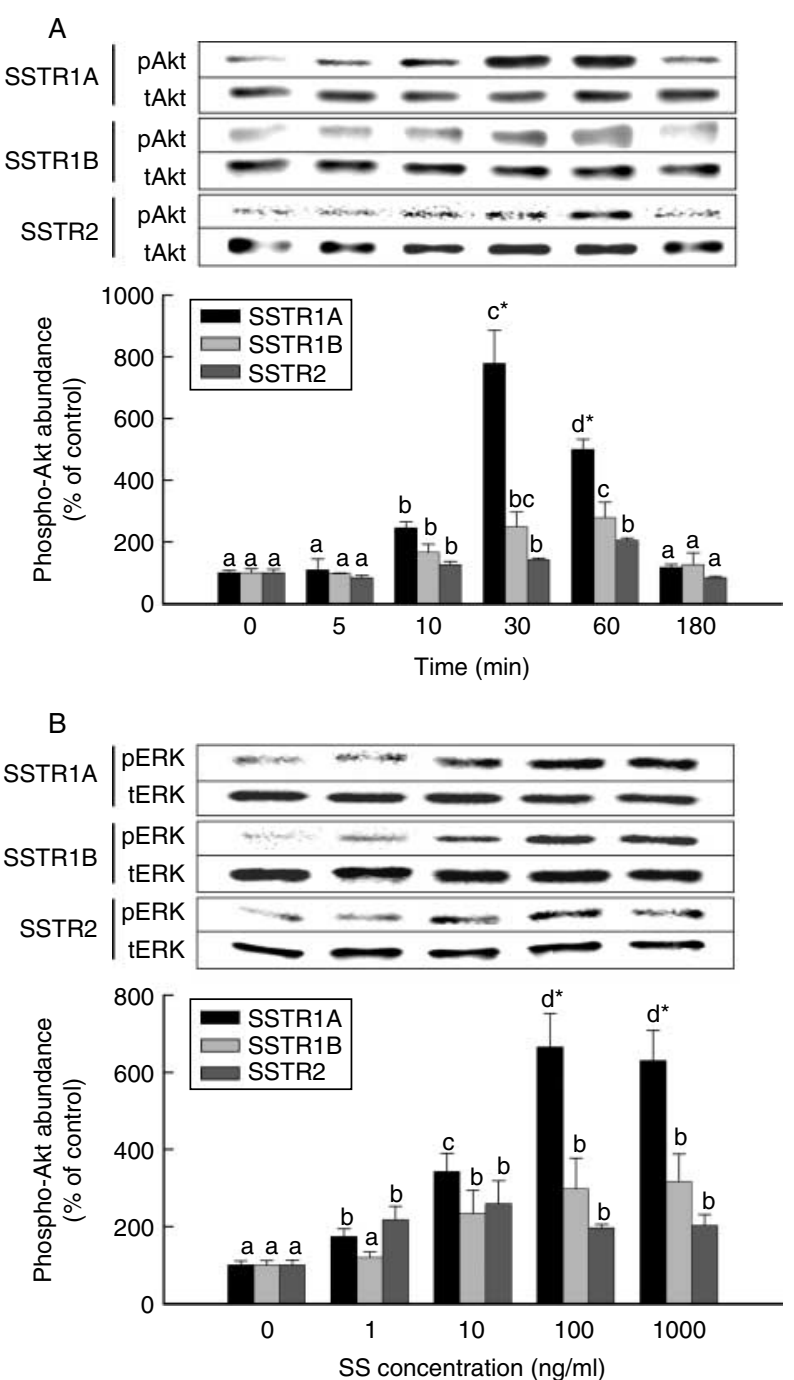

Figure 4 Effects of somatostatin (SS) on the activation of Akt in $\mathrm{CHO}-\mathrm{K} 1$ cells stably transfected with CDNA encoding rainbow trout somatostatin receptor subtype 1A (SSTR1A), somatostatin receptor subtype $1 \mathrm{~B}$ (SSTR1B), and somatostatin receptor subtype 2 (SSTR2). (A) Time-dependent phosphorylation of Akt in cells incubated with $100 \mathrm{ng} / \mathrm{ml}$ SS. (B) Concentration-dependent phosphorylation of Akt in cells incubated in the absence or presence of varying concentrations of SS for $10 \mathrm{~min}$. Lysates were separated by SDS-PAGE followed by western immunoblotting using phospho-specific (pAkt) and control (total Akt; tAkt) antibodies. Data are presented as representative immunoblots (insets) and as means \pm S.E.M. $(n=6)$ of blots quantified with an Alphalmager. For a given receptor subtype-expressing cell line (SSTR1A, SSTR1B, and SSTR2), groups with different letters are significantly different from each other $(P<0.05)$; * indicates significantly different from all other receptor subtype-expressing cell lines at a given time/concentration.

1/2 (Fig. 6A) and Akt (Fig. 6B) in CHO cells expressing SSTR1A, SSTR1B, and SSTR2, thereby linking these receptors with required G-protein activity to propagate signaling events associated with SS.

\section{SS activates transcription factors via SSTRS}

Downstream effects on transcription factors following the activation of rainbow trout SSTRs also were investigated. SS-mediated phosphorylation of Elk1, Stat3, and C/EBP $\beta$ was investigated in $\mathrm{CHO}$ cells expressing SSTR1A, SSTR1B, and SSTR2. SS induced
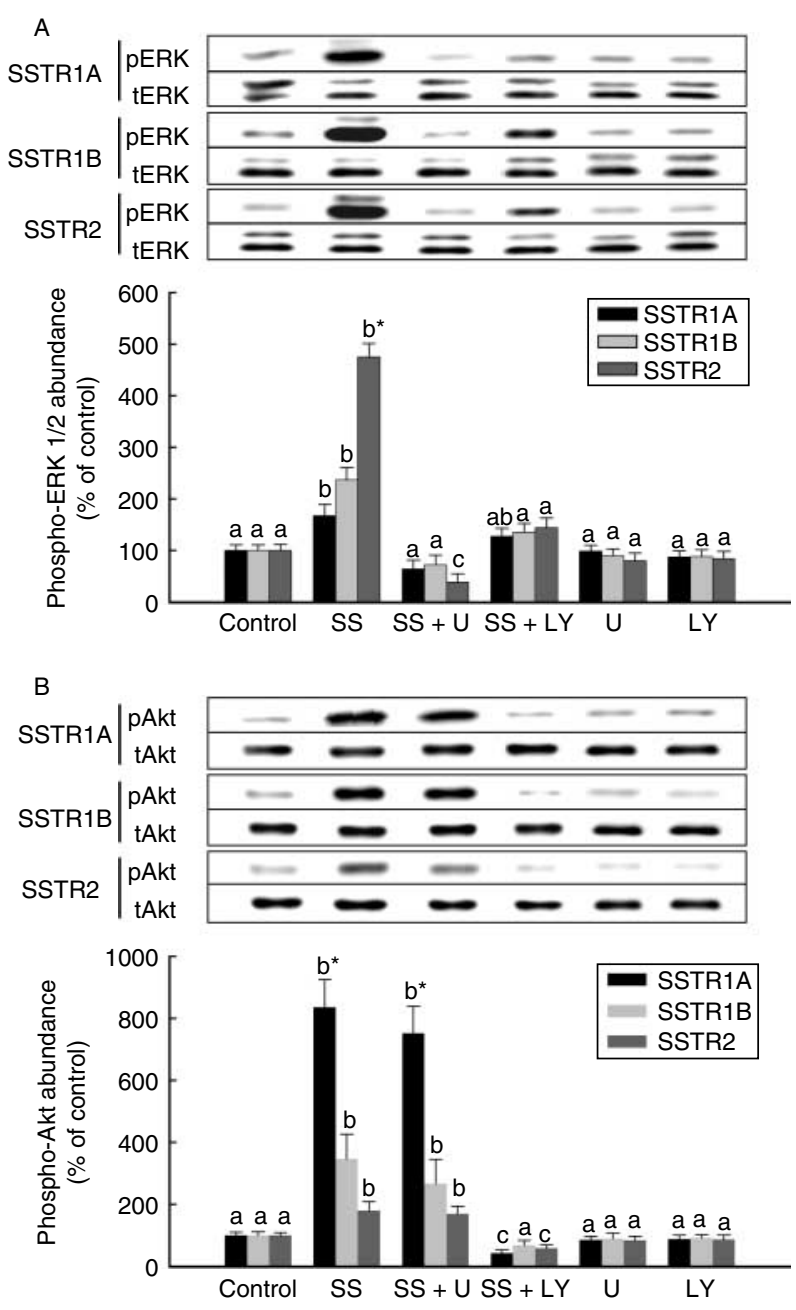

Figure 5 Effects of pathway blockade on somatostatin (SS)induced activation of ERK $(A)$ and Akt $(B)$ in CHO-K1 cells stably transfected with cDNA encoding rainbow trout somatostatin receptor subtype $1 A$ (SSTR1A), somatostatin receptor subtype 1B (SSTR1B), and somatostatin receptor subtype 2 (SSTR2). Cells were pretreated with or without inhibitor $(10 \mu \mathrm{M}$ MEK inhibitor U0126 (U) or $20 \mu \mathrm{M}$ PI3K inhibitor LY294002 (LY)) for $1 \mathrm{~h}$ and then treated with or without $100 \mathrm{ng} / \mathrm{ml} \mathrm{SS}$ for $10 \mathrm{~min}$. Lysates were separated by SDS-PAGE followed by western immunoblotting using phospho-specific (pERK $1 / 2$ or pAkt) and control (tERK $1 / 2$ or tAkt) antibodies. Data are presented as representative immunoblots (insets) and as means \pm S.E.M. $(n=6)$ of blots quantified with an Alphalmager. For a given receptor subtypeexpressing cell line (SSTR1A, SSTR1B, and SSTR2), groups with different letters are significantly different from each other $(P<0.05)$; * indicates significantly different from all other receptor subtype-expressing cell lines at a given time/concentration. 


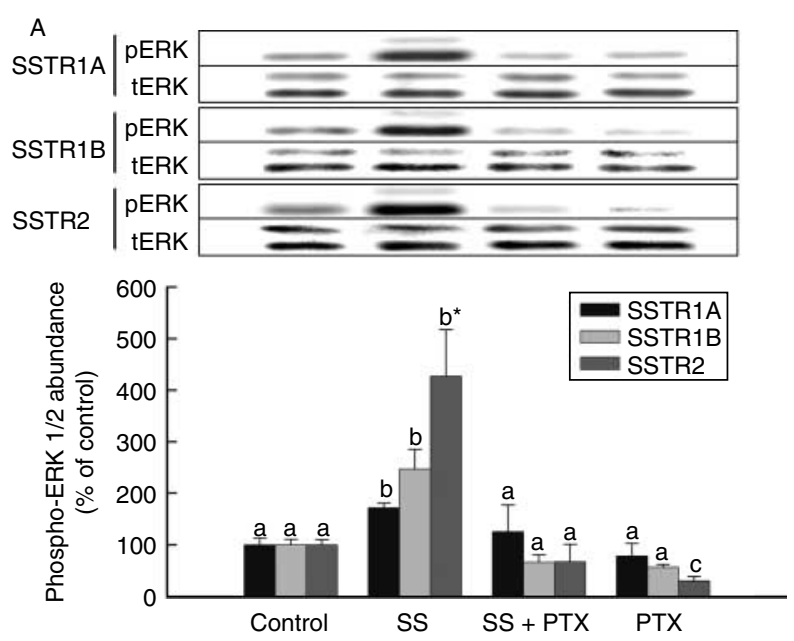

.
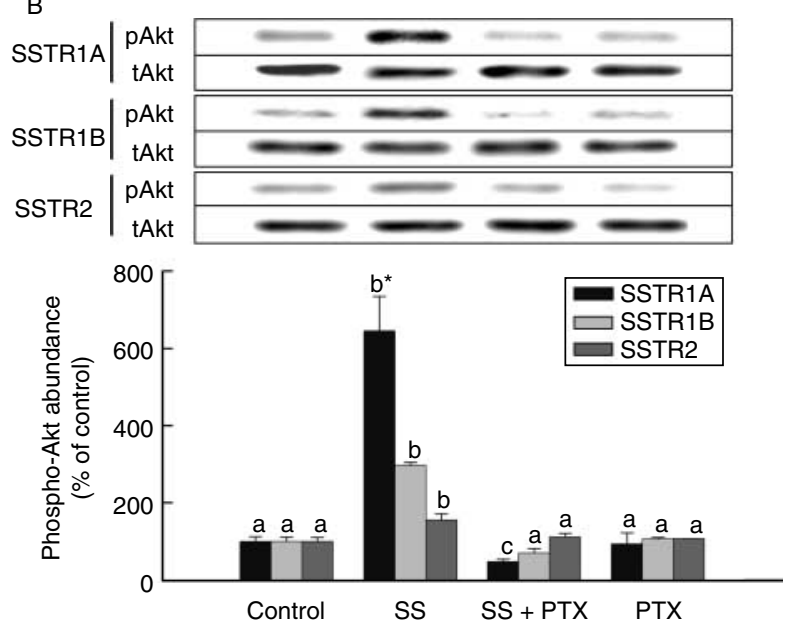

Figure 6 Effects of pertussis toxin (PTX) on somatostatin (SS)induced activation of ERK $(A)$ and Akt $(B)$ in CHO-K1 cells stably transfected with cDNA encoding rainbow trout somatostatin receptor subtype $1 \mathrm{~A}$ (SSTR1A), somatostatin receptor subtype 1B (SSTR1B), and somatostatin receptor subtype 2 (SSTR2). Cells were pretreated with or without $10 \mu \mathrm{g} / \mathrm{ml} \mathrm{PTX}$ for $6 \mathrm{~h}$ and then treated with or without $100 \mathrm{ng} / \mathrm{ml} \mathrm{SS}$ for $10 \mathrm{~min}$. Lysates were separated by SDS-PAGE followed by western immunoblotting using phospho-specific (pERK 1/2 or pAkt) and control (tERK 1/2 or tAkt) antibodies. Data are presented as representative immunoblots (insets) and as means \pm s.E.M. $(n=6)$ of blots quantified with an Alphalmager. For a given receptor subtypeexpressing cell line (SSTR1A, SSTR1B, and SSTR2), groups with different letters are significantly different from each other $(P<0.05)$; * indicates significantly different from all other receptor subtype-expressing cell lines at a given time/concentration.

the phosphorylation of Elk1 within $30 \mathrm{~min}$, and there was no significant difference in the activation of Elk1 among the different SSTR-expressing cell lines (Fig. 7A). SS also induced the activation of Stat3 within $30 \mathrm{~min}$, and as was the case with Elk1, there was no significant difference in phospho-Stat3 abundance among the three SSTR-expressing cell lines (Fig. 7B).
The $\mathrm{C} / \mathrm{EBP} \beta$ transcription factor consists of two isoforms, liver activating protein (LAP) and liver inhibitory protein (LIP), that can be differentially phosphorylated depending upon the treatment conditions. SS stimulated the phosphorylation of $\mathrm{C} / \mathrm{EBP} \beta$ $\mathrm{LAP}$, an activator of gene transcription, in all three transfected cell lines (Fig. 7C). Although LAP activation appeared greater in SSTR1B-expressing cells, there was no significant difference in the degree of LAP activation among the cell lines. The effects of SS on C/EBP $\beta$ LIP
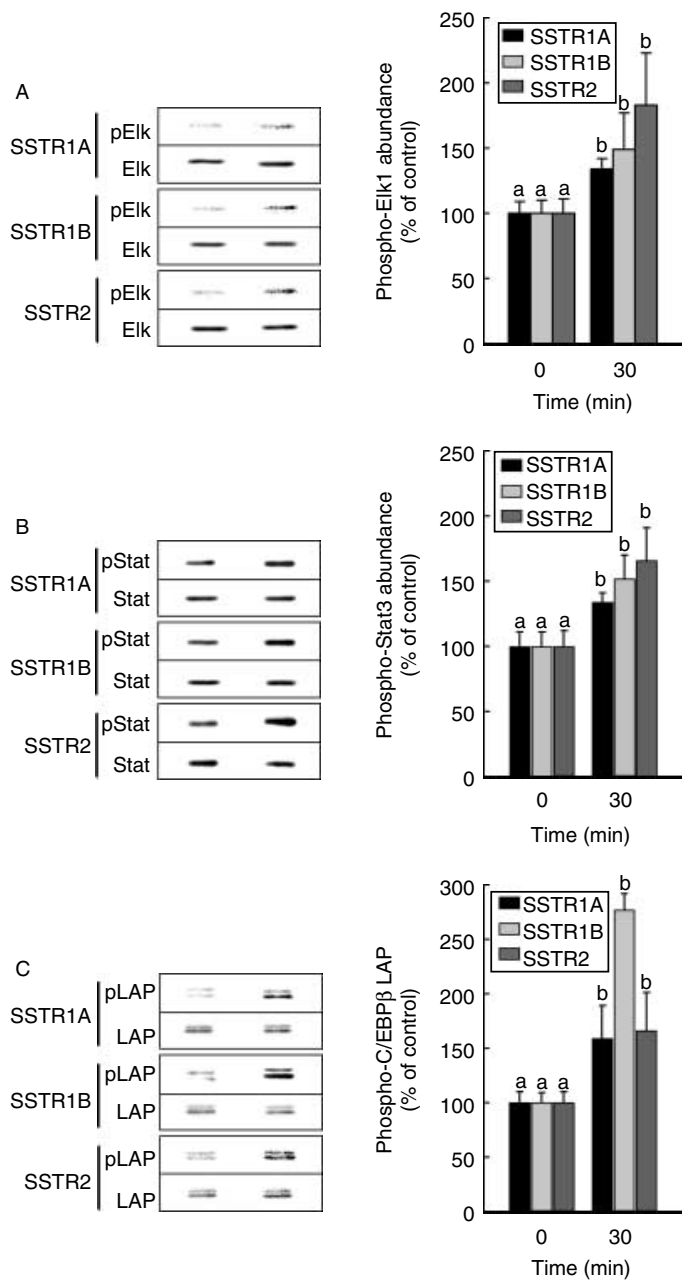

Figure 7 Effects of somatostatin (SS) on activation of the transcription factors Elk1 (A), Stat3 (B), and C/EBP $\beta$ LAP (C) in $\mathrm{CHO}-\mathrm{K} 1$ cells stably transfected with cDNA encoding rainbow trout somatostatin receptor subtype 1A (SSTR1A), somatostatin receptor subtype 1B (SSTR1B), and somatostatin receptor subtype 2 (SSTR2). Cells were incubated with $100 \mathrm{ng} / \mathrm{ml} \mathrm{SS}$ for $30 \mathrm{~min}$, and the lysates were separated by SDS-PAGE followed by western immunoblotting using phospho-specific (pElk1, pStat3, and pLAP) and control (total Elk1, total Stat3, and total LAP) antibodies. Data are presented as representative immunoblots (insets) and as means \pm S.E.M. $(n=6)$ of blots quantified with an Alphalmager; groups with different letters are significantly different from each other $(P<0 \cdot 05)$. 
activation in the SSTR-transfected cells also were investigated, and no significant effect on LIP phosphorylation was observed in any of the cell lines (data not shown).

\section{Discussion}

In this study, we took advantage of stably transfected CHO-K1 cells to establish, for the first time, receptoreffector pathway linkages for teleost SSTRs. The transfected CHO-K1 cells synthesized and translated trout SSTR mRNAs and correctly targeted the receptors to the cell surface; binding analysis confirmed that each of the SSTR-expressing cell lines (SSTR1A, SSTR1B, and SSTR2) were functional and bound $\left[{ }^{125} \mathrm{I}\right]-\mathrm{SS}-$ observations that were consistent with our previous results in which expressed SSTR1A and SSTR1B bound $\left[{ }^{125} \mathrm{I}\right]$-SS with high affinity (Gong et al. 2004). The present findings demonstrated linkages between fish SSTRs and the ERK and PI3K/Akt pathways and provided important insight into the molecular mechanisms by which SSs may elicit specific physiological effects in target cells.

Rainbow trout SSTRs activate the ERK signaling pathway. This conclusion is supported by the observation that SS stimulated ERK 1/2 phosphorylation in each of the SSTR-expressing cell lines. Moreover, SS stimulation of c-Raf in each of the cell lines suggested that ERK activation proceeds from the Raf-MEK-ERK cascade. Furthermore, blockade of the ERK pathway with the MEK inhibitor, U0126, prevented SS-induced phosphorylation of ERK 1/2. These findings are consistent with previous studies in native systems of fish in which SS induced ERK activation in hepatocytes and gill filaments (Hagemeister \& Sheridan 2008, Hanson et al. 2010). The involvement of ERK in conducting SS intracellular signaling also has been studied in mammalian systems, but the nature of the response appears cell line specific. For example, in human A431 cells, SS increased ERK activation (Stetak et al. 2001), whereas in human MDA-231 cells, SS decreased ERK activation (Siriwardana et al. 2006). Interestingly, in mouse MIN6 cells, SS has a dual effect on ERK activity, with an initial PTX-independent ERK activation followed by a later partially PTX-sensitive inhibition of ERK (Yoshitomi et al. 1997).

Rainbow trout SSTRs also activate the PI3K/Akt pathway. This conclusion is supported by the observation that in all three rainbow trout SSTR-expressing $\mathrm{CHO}$ cell lines, SS induced the phosphorylation of Akt, a signaling element downstream of PI3K. In addition, the PI3K inhibitor, LY294002, blocked SS-stimulated Akt phosphorylation. These findings are consistent with previous studies in trout that showed that SS activates Akt in liver cells and gill filaments (Hagemeister \& Sheridan 2008, Hanson et al. 2010). As was the case for the involvement of ERK in the mechanism of SS action in mammalian systems, there is evidence that SS can either activate or inhibit PI3K/Akt pathway, depending on the cell system under study. For example, in human A431 cells, SS activated PI3K as well as the cytosolic tyrosine kinase c-Src, whereas in rat $\mathrm{GH}_{3}$ cells (Stetak et al. 2001), SS reduced PI3K activity, which led to the inhibition of 3-phosphoinositide dependent protein kinase-1 (PDK1) and Akt and the activation of glycogen synthase kinase-3 $\beta$ (Theodoropoulou et al. 2006).

This study revealed, however, that there were significant differences in the efficacy of the trout SSTR subtypes to activate the ERK and PI3K/Akt pathways. The PI3K/Akt pathway was activated to a greater extent through SSTR1A than through either SSTR1B or SSTR2, whereas the ERK pathway was activated to a greater extent though SSTR2 than through either SSTR1A or SSTR1B. The molecular basis(es) for these differential linkages is(are) not known, but it(they) probably results(result) from structural differences among the receptors. Despite the similarity among the trout SSTRs, there are several notable differences in the third intracellular loops and C-termini (there is $94 \%$ identity in amino acid between SSTR1A and SSTR1B, and $45-46 \%$ identity between SSTR2 and either SSTR1A or SSTR1B; Slagter \& Sheridan 2004, Kittilson J, Slagter B, Yak T \& Sheridan MA, unpublished) segments that have been found to play an important role in receptor coupling to second messenger systems and in agonistinduced receptor internalization in mammals (Hukovic et al. 1998). There also have been a few reports of SSTR subtype-effector pathway linkages in mammalian systems. For example, SSTR1 mediated the activation of the ERK pathway in human SH-SY5Y cells and in BON-1 cells (Stirnweis et al. 2002, Ludvigsen et al. 2004). In addition, the involvement of the c-Raf-MEK-ERK pathway was critical to SS activation of IKK/NFKB through mammalian SSTR2 in rat AR4-2J cells (Liu \& Wong 2005). Similarly, SSTR1 and SSTR2 mediated SS-stimulated PI3K-dependent activation of Akt in human ocular ciliary epithelium and rat Kupffer cells (Valatas et al. 2004, Ghosh et al. 2006). In contrast, SSTR2 mediated SS inhibition of rat pancreatic cell proliferation via PI3K pathway inhibition without affecting the ERK pathway (Charland et al. 2001).

There are multiple points of communication between the PI3K/Akt pathway and the ERK pathway as the latter integrates signals from a host of effector molecules (Liu \& Wong 2005). PI3Ks can enhance ERK $1 / 2$ activation through stimulation of $\mathrm{G}_{\beta \gamma}$ subunits that are upstream of ERK (Yart et al. 2002). Also, studies demonstrate a significant relationship between c-Raf, a factor conventionally placed in the MAPK/ERK pathway, and the PI3K/Akt pathway, as 
Akt is able to directly activate c-Raf in mammalian cells (Zimmermann \& Moelling 1999, Reusch et al. 2001). In this study, cross talk between the ERK and PI3K/Akt pathways was suggested by the ability of the PI3K inhibitor to block/nearly block ERK phosphorylation mediated through SSTR1A, SSTR1B, and SSTR2. Given the activation of c-Raf in all the trout SSTRexpressing cell lines, it is possible that c-Raf serves as a nexus between the PI3K and ERK pathways, establishing a PI3K-c-Raf-MEK-ERK cascade. It should be noted that the extent to which such cross talk may occur must be governed in some manner in order to explain the observed differential activation of Akt by SSTR1A and of ERK by SSTR2. It should also be noted that the PI3K inhibitor knocked down most but not all SS-induced activation of ERK, suggesting that other upstream elements besides PI3K may serve to activate the c-Raf-MEK-ERK cascade. One possible alternative upstream mechanism is the PLC-protein kinase C (PKC) pathway, which has been shown to be activated in mammalian systems through various SSTRs including SSTR2 (Cervia \& Bagnoli 2007). SS signaling through PKC has been demonstrated in goldfish pituitary (Yunker et al. 2003).

All SSTRs characterized to date, including those from fish, are members of the rhodopsin subfamily G-protein-coupled receptors (Moller et al. 2003, Nelson \& Sheridan 2005). Multiple G-protein types, primarily from the $\mathrm{G}_{\mathrm{i} / \mathrm{o}}$ family of inhibitory G-proteins and sensitive to inhibition by PTX, have been found to interact with SSTRs (Cervia \& Bagnoli 2007). Results from this study indicate that all three rainbow trout SSTRs were indeed linked to G-protein activity, and that the linkage between the SSTRs and the PI3K/Akt and ERK pathways depended on this activity, most likely though the $G_{\beta \gamma}$ subunits. Propagation of signal from SSTR also occurs via the $\alpha$ subunit of inhibitory proteins, which commonly leads to inhibition of adenylyl cyclase (Cervia \& Bagnoli 2007). Such a mechanism was demonstrated for two isoforms of goldfish SSTR1s expressed in COS-7 cells (Lin et al. 1999). Not all G-proteins associated with SSTR activity are susceptible to PTX inhibition (i.e. $\mathrm{G}_{\mathrm{i} / \mathrm{o}}$ ), nor do all activities associated with SSTR stimulation involve G-protein coupling. In mammalian systems, SSTR2 has been linked to protein tyrosine phosphatase and PLC via both PTX-sensitive and -insensitive means (Buscail et al. 1995), whereas SSTR1-induced activation of protein tyrosine phosphatase and $\mathrm{Na} / \mathrm{H}$ exchanger is unresponsive to PTX (Florio et al. 1994). Additionally, when expressed in a mammalian cell line and stimulated with a radiolabeled N-terminally extend form of SS (SS-28) or cortistatin (a SS homolog; cf. Gahete et al. 2008), fish SSTR3 demonstrated intracellular signaling activity that was uncorrelated to G-protein activation (Siehler et al. 2005).
This study showed that SS acting through rainbow trout SSTR1A, SSTR1B, and SSTR2 activated several transcription factors such as Elk1, Stat3, and C/EBP $\beta$ (LAP form). Elk1 is a common target for the MAPK/ERK pathway (Turjanski et al. 2007), and mammalian SSTR1 previously has been linked to increased Elk1 transcriptional activity through phosphorylation of the ERK pathway (Florio et al. 1999). $\mathrm{C} / \mathrm{EBP} \beta$ is the target of regulation by two signal cascades: the PI3K/Akt activation results in dephosphorylation of $\mathrm{C} / \mathrm{EBP} \beta$ from one site, whereas ERK activation promotes phosphorylation at another site of $\mathrm{C} / \mathrm{EBP} \beta$ (Schrem et al. 2004, Cui et al. 2008). Stat3 activation occurs in mammalian systems and can be modulated by both ERK and Akt (via mechanistic target of rapamycin (mTOR); Chung 1997).

The present findings reveal important SSTR-effector pathway linkages and may help explain actions of SS on growth and other processes reported previously. Given the preferential linkage of SSTR1A to the PI3K/Akt pathway observed in this study and the predominant role of PI3K/Akt in mediating SS-induced inhibition of IGF1 expression in native trout liver cells (Hagemeister \& Sheridan 2008), it is reasonable to speculate that SSTR1A mediates the action of SS on IGF1 expression in trout liver cells. On the other hand, given the preferential linkage of SSTR2 to the ERK pathway observed in this study and the predominant role of ERK in mediating SS-induced inhibition of GH receptor (GHR) expression in native trout liver cells (Hagemeister \& Sheridan 2008), it is possible that SSTR2 mediates the action of SS on GHR expression in trout liver cells. In the gill filaments of trout, however, activation of both ERK and PI3K/Akt was important to SS-induced inhibition of IGFR expression (Hanson et al. 2010), and in light of the present findings, it appears that SSTR1A and SSTR2 may both mediate the action of SS on IGFR expression in native gill filaments. Particular SSTR subtypes also have been linked to specific biological responses in mammalian systems. For example, mammalian SSTR2 appears to mediate SS inhibition of pituitary GH and pancreatic insulin (Sheridan et al. 2000).

The precise means by which the various SSTR subtypes and the effector pathways to which they link to control specific processes in native liver cells or gill filaments of trout - such as inhibition of GHR, IGF1, or IGFR expression - are not known. However, the promoter regions of the genes that encode GHR and IGF1 are known to bind various transcription factors, including $\mathrm{C} / \mathrm{EBP} \beta$ and various Stats, in both fish and mammlas (Schwartzbauer \& Menon 1998, Wang \& Jiang 2005, Wood et al. 2005), whereas the promoter of the mammalian IGFR gene is affected by a different complement of transcription factors, including p53. In light of the activation of transcription factors such as 
C/EBPs and Stat3 in all the trout SSTR-expressing cells and the observed linakge between ERK and PI3K/Akt and these transcription factors in mammalian systems (Chung 1997, Schrem et al. 2004, Cui et al. 2008), it is possible that alterations in the activity state of $\mathrm{C} / \mathrm{EBP} \beta$ and Stat3 and the modulation of GHR and IGF1 transcription may underlie SS inhibition of GHR and IGF1 expression in trout liver cells. SS-induced activation of Stat 5 also was linked to reduced hepatic GH binding in rat hepatocytes (Murray et al. 2004). It was shown recently that increased ERK and Akt activation was attended by increased p53 activation (Tanel \& Averill-Bates 2007), suggesting that SSTR1A/ SSTR2-triggered ERK and/or PI3K/Akt activation of p53 may underlie, at least in part, SS-induced inhibition of IGFR expression in native gill filaments of trout.

\section{Declaration of interest}

The authors declare that there is no conflict of interest that could be perceived as prejudicing the impartiality of the research reported.

\section{Funding}

The research was supported by a grant from the National Science Foundation, USA (IOS-0920116) to MAS.

\section{Acknowledgements}

We are grateful to Jun-Yang Gong, Heidi Malkuch, Lincoln Martin, Lindsey Norbeck, Katie Reindl, and Chad Walock for their technical assistance and valuable discussions.

\section{References}

Buscail L, Estève JP, Saint-Laurent N, Bertrand V, Reisine T, O'Carroll AM, Bell GI, Schally AV, Vaysse N \& Susini C 1995 Inhibition of cell proliferation by the somatostatin analogue RC-160 is mediated by somatostatin receptor subtypes SSTR2 and SSTR5 through different mechanisms. PNAS 92 1580-1584. (doi:10.1073/pnas.92.5.1580)

Cervia D \& Bagnoli P 2007 An update on somatostatin receptor signaling in native systems and new insight on their pathophysiology. Pharmacology and Therapeutics 116 322-341. (doi:10.1016/ j.pharmthera.2007.06.010)

Charland S, Boucher MJ, Houde M \& Rivard N 2001 Somatostatin inhibits Akt phosphorylation and cell cycle entry, but not p42/p44 mitogen-activated protein (MAP) kinase activation in normal and tumoral pancreatic acinar cells. Endocrinology 142 121-128. (doi:10.1210/en.142.1.121)

Chung J, Uchida E, Grammer TC \& Blenis J 1997 Stat3 serine phosphorylation by ERK-dependent and independent pathways negatively modulates its tyrosine phosphorylation. Molecular and Cellular Biology 17 6508-6516.

Cui TX, Kwok R \& Schwartz J 2008 Cooperative regulation of endogenous cAMP-response element binding protein and CCAAT/enhancer-binding protein beta in GH-stimulated c-fos expression. Journal of Endocrinology 196 89-100. (doi:10.1677/ JOE-07-0169)
Florio T, Rim C, Hershberger RE, Loda M \& Stork PJ 1994 The somatostatin receptor SSTR1 is coupled to phosphotyrosine phosphatase activity in CHO-K1 cells. Molecular Endocrinology 8 1289-1297. (doi:10.1210/me.8.10.1289)

Florio T, Thellung S, Arena S, Corsaro A, Spaziante R, Gussoni G, Acuto G, Giusti M, Giordano G \& Schettini G 1999 Somatostatin and its analog lanreotide inhibit the proliferation of dispersed human non-functioning pituitary adenoma cells in vitro. European Journal of Endocrinology 141 396-408. (doi:10.1530/eje.0.1410396)

Florio T, Thellung S, Arena S, Corsaro A, Bajetto A, Schettini G \& Stork PJ 2000 Somatostatin receptor 1 (SSTR1)-mediated inhibition of cell proliferation correlates with the activation of the MAP kinase cascade: role of the phosphotyrosine phosphatase SHP-2. Journal of Physiology 94 239-250. (doi:10.1016/S09284257(00)00214-X)

Gahete MD, Duran-Prado M, Luque RM, Martinez-Fuentes R, VazquezMartinez MM, Malagon MM \& Castano JP 2008 Are somatostatin and cortistatin two siblings in regulating endocrine secretions? In vitro work ahead Molecular and Cellular Endocrinology 286 128-134. (doi:10.1016/j.mce.2007.11.013)

Gahete MD, Cordoba-Chacon J, Duran-Prado M, Malagon MM, Martinez-Fuentes AJ, Gracia-Navarro F, Luque RM \& Castano JP 2010 Somatostatin and its receptors from fish to mammals. Annals of the New York Academy of Sciences 1200 43-52. (doi:10.1111/j.17496632.2010.05511.x)

Ghosh S, Choritz L, Geibel J \& Coca-Prados M 2006 Somatostatin modulates PI3K-Akt, eNOS and NHE activity in the ciliary epithelium. Molecular and Cellular Endocrinology 253 63-75. (doi:10.1016/j.mce.2006.05.002)

Gong JY, Kittilson JD, Slagter BJ \& Sheridan MA 2004 The two subtype 1 somatostatin receptors of rainbow trout, Tsst1A and Tsst1B, possess both distinct and overlapping ligand binding and agonistinduced regulation features. Comparative Biochemistry and Physiology, Part B 138 295-303. (doi:10.1016/j.cbpc.2004.04.005)

Hagemeister AL \& Sheridan MA 2008 Somatostatin inhibits hepatic growth hormone receptor and insulin-like growth factor I mRNA expression by activating the ERK and PI3K signaling pathways. American Journal of Physiology 295 R490-R497. (doi:10.1152/ajpcell. 00188.2008)

Hanson A, Poudyal D, Hagemeister A, Reindl KM \& Sheridan MA 2010 The ERK and PI3K signaling pathways mediate inhibition of insulinlike growth factor-1 receptor mRNA expression by somatostatin. Molecular and Cellular Endocrinology 315 57-62. (doi:10.1016/j.mce. 2009.09.034)

Hukovic N, Panetta R, Kumar U, Rocheville M \& Patel YC 1998 The cytoplasmic tail of the human somatostatin receptor type five is crucial for interaction with adenylyl cyclase and in mediating desensitization and internalization. Journal of Biological Chemistry 273 21416-21422. (doi:10.1074/jbc.273.33.21416)

Klein SE \& Sheridan MA 2008 Somatostatin signaling and the regulation of growth and metabolism in fish. Molecular and Cellular Endocrinology 286 148-154. (doi:10.1016/j.mce.2007.08.010)

Lahlou H, Saint-Laurent N, Esteve JP, Eychene A, Pradayrol L, Pyronnet S \& Susini C 2003 sst2 Somatostatin receptor inhibits cell proliferation through Ras-, Rap1-, and B-Raf-dependent ERK2 activation. Journal of Biological Chemistry 278 39356-39371. (doi:10. 1074/jbc.M304524200)

Lin X \& Peter RE 2001 Somatostatins and their receptors in fish. Comparative Biochemistry and Physiology, Part B 129 543-550. (doi:10.1016/S1096-4959(01)00362-1)

Lin X, Janovik J, Brothers S, Conn PP \& Peter RE 1999 Molecular cloning and expression of two type one somatostatin receptors in goldfish brain. Endocrinology 140 5211-5219. (doi:10.1210/en.140. $11.5211)$

Liu AM \& Wong YH 2005 Activation of nuclear factor $\kappa$ B by somatostatin type 2 receptor in pancreatic acinar AR42J cells involves $\mathrm{G} \alpha_{14}$ and multiple signaling components: a mechanism 
requiring protein kinase $\mathrm{C}$, calmodulin-dependent kinase II, ERK, and c-Src. Journal of Biological Chemistry 80 34617-34625. (doi:10. 1074/jbc.M504264200)

Ludvigsen E, Stridsberg M, Taylor JE, Culler MD, Oberg K \& Janson ET 2004 Subtype selective mechanisms of somatostatin and somatostatin analogues with sst $_{1}$, sst $_{2}$, and sst $_{5}$ in BON-1 cells. Medical Oncology 21 285-296. (doi:10.1385/MO:21:3:285)

Moller LN, Stidsen CE, Hartmann C \& Holst JJ 2003 Somatostatin receptors. Biochimica et Biophysica Acta 1616 1-84. (doi:10.1016/ S0005-2736(03)00235-9)

Murray RD, Kim K, Ren SG, Chelly M, Umehara Y \& Melmed S 2004 Central and peripheral actions of somatostatin on the growth hormone-IGF-1 axis. Journal of Clinical Investigation 114 349-356. (doi:10.1172/JCI19933)

Nelson LE \& Sheridan MA 2005 Regulation of somatostatins and their receptors in fish. General and Comparative Endocrinology 142 117-133. (doi:10.1016/j.ygcen.2004.12.002)

Pesek MJ, Howe N \& Sheridan MA 1998 Somatostatin binding to hepatocytes isolated from rainbow trout, Oncoryhnchus mykiss, is modulated by insulin and glucagon. General and Comparative Endocrinology 112 183-190. (doi:10.1006/gcen.1998.7154)

Reusch HP, Zimmermann S, Schaefer M, Paul M \& Moelling K 2001 Regulation of Raf by Akt controls growth and differentiation in vascular smooth muscle cells. Journal of Biological Chemistry 276 33630-33637. (doi:10.1074/jbc.M105322200)

Schrem H, Klempnauer J \& Borlak J 2004 Liver-enriched transcription factors in liver function and development. Part II: the C/EBPs and $\mathrm{D}$ site-binding protein in cell cycle control, carcinogenesis, circadian gene regulation, liver regeneration, apoptosis, and liverspecific gene regulation. Pharmacological Reviews 56 291-330. (doi:10.1124/pr.56.2.5)

Schwartzbauer G \& Menon RK 1998 Regulation of growth hormone receptor gene expression. Molecular Genetics and Metabolism 63 243-253. (doi:10.1006/mgme.1998.2685)

Sheridan MA \& Hagemeister AL 2010 Somatostatin and somatostatin receptors in fish growth. General and Comparative Endocrinology 167 360-365. (doi:10.1016/j.ygcen.2009.09.002)

Sheridan MA, Kittilson JD \& Slagter BA 2000 Structure-function relationships of the somatostatin peptide hormone family. American Zoologist 40 269-286. (doi:10.1668/00031569(2000)040 [0269:SFROTS]2.0.CO;2)

Siehler S, Nunn C, Zupanc GK \& Hoyer D 2005 Fish somatostatin sst3 receptor: comparison of radioligand and GTPgammaS binding, adenylate cyclase and phospholipase $\mathrm{C}$ activities reveals different agonist-dependent pharmacological signatures. Autonomic and Autacoid Pharmacology 25 1-16. (doi:10.1111/j.1474-8673.2004. 00325.x)

Siehler S, Nunn C, Hannon J, Feuerbach D \& Hoyer D 2008 Pharmacological profile of somatostatin and cortistatin receptors. Molecular and Cellular Endocrinology 286 26-34. (doi:10.1016/j.mce.2007.12.007)

Siriwardana G, Bradford A, Coy D \& Zeitler P 2006 Autocrine/paracrine regulation of breast cancer cell proliferation by growth hormone releasing hormone via Ras, Raf, and mitogen-activated protein kinase. Molecular Endocrinology 20 2010-2019. (doi:10.1210/ me.2005-0001)

Slagter BJ \& Sheridan MA 2004 Differential expression of two somatostatin receptor subtype 1 mRNAs in rainbow trout (Oncorhynchus mykiss). Journal of Molecular Endocrinology 32 165-177. (doi:10.1677/jme.0.0320165)

Stetak A, Csermely P, Ullrich A \& Keri G 2001 Physical and functional interactions between protein tyrosine kinase phosphatase alpha, PI3-kinase, and PKCdelta. Biochemical and Biophysical Research Communications 288 564-572. (doi:10.1006/ bbrc.2001.5811)

Stirnweis J, Boehmer FD \& Liebmann C 2002 The putative somatostatin antagonist, cyclo-(7-aminoheptanoyl-Phe-D-Trp-LysThr\{BZL $\} 0$, may act as potent antiproliferative agonist. Peptides $\mathbf{2 3}$ 1503-1506. (doi:10.1016/S0196-9781 (02)00089-X)

Tanel A \& Averill-Bates DA 2007 P38 and ERK mitogen activated protein kinases mediate acrolein-induced apoptosis in Chinese hamster ovary cells. Cellular Signalling 19 968-977. (doi:10.1016/ j.cellsig.2006.10.014)

Theodoropoulou M, Zhang J, Laupheimer S, Paez-Pereda M, Erneux C, Florio T, Pagotto U \& Stalla GK 2006 Octreotide, a somatostatin analogue, mediates its antiproliferative action in pituitary tumor cells by altering phosphatidylinositol 3-kinase signaling and inducing Zacdlexpression. Cancer Research 66 1576-1582. (doi:10.1158/0008-5472.CAN-05-1189)

Tostivint H, Lihrmann I \& Vaudry H 2008 New insights into the molecular evolution of the somatostatin family. Molecular and Cellular Endocrinology 286 5-17. (doi:10.1016/j.mce.2008.02.029)

Turjanski AG, Vaqué JP \& Gutkind JS 2007 MAP kinases and the control of nuclear events. Oncogene 26 3240-3253. (doi:10.1038/ sj.onc.1210415)

Valatas V, Kolios G, Manousou P, Xidakisc C, Notas G, Ljumovic D \& Kouroumalis EA 2004 Secretion of inflammatory mediators by isolated rat Kupffer cells: the effect of octreotide. Regulatory Peptides 120 215-225. (doi:10.1016/j.regpep.2004.03.009)

Van Op den bosch J, Adriaensen D, Van Nassauw L \& Timmermans J-P 2009 The role(s) of somatostatin, structurally related peptides and somatostatin receptors in the gastrointestinal tract: a review. Regulatory Peptides 156 1-8. (doi:10.1016/j.regpep.2009.04.003)

Wang Y \& Jiang H 2005 Identification of a distal STAT5-binding DNA region that may mediate growth hormone regulation of insulin-like growth factor I gene expression. Journal of Biological Chemistry 280 10955-10963. (doi:10.1074/jbc.M412808200)

Wood AW, Duan C \& Bern HA 2005 Insulin-like growth factor signaling in fish. International Reviews of Cytology 243 215-285. (doi:10.1016/S0074-7696(05)43004-1)

Yart A, Roche S, Wetzker R, Laffargue M, Tonks N, Mayeux P, Chap H \& Raynal P 2002 A function for phosphoinositide 3-kinase beta lipid products in coupling beta gamma to Ras activation in response to lysophosphatidic acid. Journal of Biological Chemistry 277 21167-21178. (doi:10.1074/jbc.M110411200)

Yoshitomi H, Fujii Y, Miyazaki M, Nakajima N, Inagaki N \& Seino S 1997 Involvement of MAP kinase and c-fos signaling in the inhibition of cell growth by somatostatin. American Journal of Physiology 272 E769-E774.

Yunker WK, Smith S, Graves C, Davis PJ, Unniappan S, Rivier JE, Petrer RE \& Chang JP 2003 Endogenous hypothalamic somatostatins differentially regulate growth hormone secretion from goldfish pituitary somatotropes in vitro. Endocrinology 144 4031-4041. (doi:10.1210/en.2003-0439)

Zimmermann S \& Moelling K 1999 Phosphorylation and regulation of Raf by Akt (protein kinase B). Science 286 1741-1744. (doi:10.1126/ science.286.5445.1741)

Received in final form 23 July 2010

Accepted 23 August 2010

Made available online as an Accepted Preprint 23 August 2010 